\title{
EFFECT OF ELECTRIC CONDUCTING ELEMENT ON INDICATORS OF LINEAR PULSE ELECTROMECHANICAL CONVERTER INDUCTION TYPE
}

$\quad$ Journal
Publisher
ISSN
Issue
Pages

\author{
Tekhnichna elektrodynamika \\ Institute of Electrodynamics National Academy of Science of Ukraine \\ 1607-7970 (print), 2218-1903 (online) \\ No 3, 2020 (May/June) \\ $22-29$
}

\author{
Author \\ V.F. Bolyukh* \\ National Technical University "Kharkiv Polytechnic Institute", \\ st. Kirpicheva, 2, Kharkov, 61002, Ukraine, \\ e-mail: vfbolyukh@gmail.com \\ * ORCID ID : https://orcid.org/0000-0001-9115-7828
}

\begin{abstract}
The purpose of the article is to study the influence of geometric parameters and the location of a coaxially located electrically conductive element (ECE), made in the form of a thin-walled disk, ring or hollow cylinder, on the characteristics and performance of an induction-type linear pulse electromechanical converter (LPEC). A mathematical model has been developed that describes the electromechanical and thermal processes in an induction-type LPEC using the concentrated parameters of active elements. It is shown that the ECE, coaxially mounted near the inductor winding, has a negative effect on the performance of the LPEC. The smallest value of the converter efficiency of $6.1 \%$ occurs when ECE is used in the form of a thin copper disk $0.5 \mathrm{~mm}$ high, in which the radial dimensions are similar to the sizes of the windings of the inductor and the armature installed at a minimum distance from the inductor. Moreover, the temperature rise of the electrically conductive element is maximum and equal to $51^{\circ} \mathrm{C}$. With an increase in the thickness of the ECE and with its removal from the inductor, the efficiency of the LPEC increases, and the excess of the temperature of the ECE decreases. When removing a disk $E C E$ with a height of $1.0 \mathrm{~mm}$ at a distance of $10 \mathrm{~mm}$ from the inductor, the efficiency of the $\angle P E C$ is $12.6 \%$, and the excess of the ECE temperature is $6^{\circ} \mathrm{C}$. References 14 , figures 6 .
\end{abstract}


Key words: linear pulse electromechanical converter of induction type, electrically conductive element, mathematical model, electromechanical and thermal processes and indicators.

Received: 16.02 .2020

Accepted: 16.03 .2020

Published: 05.05.2020

The work was done on the state budget theme "Improvement of technical systems and devices due to impulse electromechanical converters and electrophysical technologies". State Registration Number: 0117U004881. (01/01/2017 - 31/12/2018).

\section{References}

1. Angquist L., Baudoin A., Norrga S. et al. Low-cost ultra-fast DC circuit-breaker: Power electronics integrated with mechanical switchgear. IEEE International Conference on Industrial Technology

(ICIT). Lyon. 2018.

Pp. 1708-1713. DOI:

https://doi.org/10.1109/ICIT.2018.8352439

2. Bissal A., Magnusson J., Engdahl G. Comparison of two ultra-fast actuator concept. IEEE Transactions on Magnetics

. 2012. Vol. 48. No 11. Pp. 3315-3318. DOI:

https://doi.org/10.1109/tmag.2012.2198447

3. Soda R., Tanaka K., Takagi K., Ozaki K. Simulation-aided development of magnetic-aligned compaction process with pulsed magnetic field. Powder Technology. 2018. Vol. 329. No 15. Pp. 364-370. DOI:

https://doi.org/10.1016/j.powtec.2018.01.035

4. Bolyukh V.F., Dan'ko V.G., Oleksenko S.V. The effect of an external shield on the efficiency of an induction-type linear-pulse electromechanical converter. Russian Electrical Engineering.

2018. Vol. 89. Issue 4. Pp. 275-281. DOI:

https://doi.org/10.3103/S106837121804003X 


\section{. (Rus)}

5. Bolyukh V.F., Katkov I.I. Cryogenic cooling system "Krioblast" increased efficiency and lowered the operation time of protective electrical induction-induced devices. ASME International Mechanical Engineering Congress and Exposition

. San Diego, CA, US. 15-21 November 2013. Vol. 8B. Code 105847. Pp. V08BT09A003. DOI: https://doi.org/10.1115//MECE2013-62383

6. Bolyukh V.F., Vinnichenko A.I. Concept of an induction-dynamic catapult for a ballistic laser gravimeter. Measurement Techniques. 2014. Vol. 56. Issue 10. Pp. 1098-1104. DOI: http s://doi.org/10.1007/s11018-014-0337-z

. (Rus)

7. Go B.-S., Le D.-V., Song M.-G. et al. Design and electromagnetic analysis of an induction-type coilgun system with a pulse power module. IEEE Transactions on plasma science . 2019. Vol. 47, No. 1. Pp.

971-976. DOI: oi.org/10.1109/TPS.2018.2874955

8. Gorodzha K.A., Podoltsev O.D., Troshchinsky B.A. Electromagnetic processes in a pulsed electrodynamic emitter for the excitation of elastic vibrations in concrete structures. Tekhnichna Elektrodynamika

. 2019. No 3. Pp. 23-28. DOI:

https://doi.org/10.15407/techned2019.03.023

. (Ukr)

9. Kondratenko I.P., Zhiltsov A.V., Paschin M.O., Vasyuk V.V. Choice of parameters of induction electromechanical converter for electrodynamic processing of welded joints. Tekhnich na Elektrodynamika

. 2017. No 5. Pp. 83-88. DOI:

https://doi.org/10.15407/techned2017.05.083

. (Ukr)

10. Kondratiuk M., Ambroziak L. Concept of the magnetic launcher for medium class unmanned aerial vehicles designed on the basis of numerical calculations. Journal of Theoretical and Applied Mechanics

. 2016. Vol. 54, Issue 1. Pp. 163-177. DOI:

https://doi.org/10.15632/jtam-pl.54.1.163

11. Lim D.K., Woo D.K., Kim I.W. Characteristic analysis and design of a Thomson coil actuator using an analytic method and a numerical method. IEEE Transactions on Magnetics. 2013. Vol. 49. No. 12. Pp. 5749-5755. URL:

https://www.ingentaconnect.com/content/iee/00189464/2013/00000049/00000012/art00024;jse ssionid=1jo2grl3onerq. $x$-ic-live-03

DOI:

https://doi.org/10.1109/TMAG.2013.2272561

12. Vilchis-Rodriguez D.S., Shuttleworth R., Barnes M. Modelling thomson coils with axis-symmetric problems: practical accuracy considerations. IEEE Transactions on Energy Conversion . 2017. Vol. 32. No.

2. Pp. 629-639. DOI: 
13. Bach Ju., Bricquet $\mathrm{C}$. Electric switching device with ultra-fast actuating mechanism and hybrid switch comprising one such device. US Patent 8686814, H01H77/00. Assignee: Schneider Electric Industries SAS. 01.04.2014.

14. Zhou Y., Huang Y., Wen W. et al. Research on a novel drive unit of fast mechanical switch with modular double capacitors. Journal of Engineering. 2019. Vol. 2019. Issue 17. Pp.

4345-4348. DOI:

https://doi.org/10

$.1049 /$ joe.2018.8148

PDF

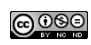

This work is licensed under a Creative Commons Attribution-NonCommercial-NoDerivatives 4.0 International License 